\title{
Eschatological Folk Songs and Poetry in the Manuscript Tradition of the Russian Old Believers of Latgale
}

\author{
Tatiana Filosofova \\ University of Kentucky, \\ Lexington, Kentucky, USA
}

\begin{abstract}
Eschatological beliefs and teachings form the core of the Russian Old Believer theological doctrine and world view and are broadly reflected in their writings and oral literature. This article sets out to examine the particularities of the body of the eschatological folk songs and poetry known to the Russian Old Believers who live in the eastern part of contemporary Latvia (Latgalia). The Latgalian Old Believer community is considered one of the richest, well preserved and fully functional communities of the bespopovtsy (the "priestless") branch in Europe today. This current research was based on material from the manuscript collections held in the Drevlekhranilishche IRLI (St. Petersburg, Russia) and field work carried out in the Latgalian community between 2007 and 2010. First, the article describes the repertoire of eschatological songs and poetry that form the core of the written anthologies widely circulated in the Latgalian tradition. It then moves on to analyze how the eschatological teachings were interpreted in folk songs and poetry. Specifically, the research focuses on the folk interpretation of the timing of the end of the world, the figure of the Antichrist and his realm. Finally, the article examines some linguistic particularities of the religious songs and poetry and how they were completed, edited and recorded in the Old Believer manuscripts.
\end{abstract}

FOLKLORICA 2013, Vol. XVII 
Eschatological Teachings of the Russian Old Believers and the Nature of their Cultural Heritage

Eschatological beliefs and teachings form the core of Russian Old Believer theological doctrine and world view and, as a result, are broadly reflected in their writings and oral literature. Certainly, the Old Believers are not unique in this regard. As the prominent scholar, G. P. Fedotov, states in his classical work on Russian folk religious songs; "Eschatology holds the key to any religion. It is here the ends meet; where the concealed nerve of a religious mentality reveals itself. The purpose of any religion is to solve the problem of death" [Fedotov 1991: 105]. It is accepted by scholars that eschatological teachings deal with "the four last things: death, judgment, heaven and hell" [Oxford English Dictionary on line: eschatology, def.] at two levels: firstly, at a personal level, concerning an individual's death, afterlife, sins and punishment and, secondly, at the global level, concerning the end of the world, the Second coming and the Last Judgment.

Old Believer culture, essentially in its nature Orthodox and written, is guided by medieval Russian culture and early Christian literature from before the time of the Russian Orthodox Church reform of 1653-1666. (1) The Old Believers inherited and adapted a wealth of works dealing with all aspects of eschatological teachings, including those written by early Christian and medieval Orthodox Russian theologians, apocrypha, and a rich body of mainstream Russian oral literature [Belousov 1979; Belousov 1980; Gur'ianova 1996; Izbrannye tvoreniia sviatykh ottsov 1998. Sakharov 1879; Zenkovsky 2009]. However, what distinguishes Old Believer culture and beliefs is their original interpretation, in their writings and oral literature, of certain aspects of Christian eschatological teachings.

The Old Believer movement emerged in response to the controversial Russian Orthodox Church reform of 1653-1666; they attempted to preserve the patriarchal nature of their community, pre-reform ceremonies and to keep sacred books free from innovations or corrections. However, from the start religious dissidents were faced with an extremely challenging task, namely

FOLKLORICA 2013, Vol. XVII 
finding a way to lead an Orthodox Christian life without the spiritual guidance of the Church that had been rejected by the Old Believers as an institution after the reform. The endless disputes and disagreements about the way forward, in the absence of the institutional body of the Church, emerged right at the start of the break-away movement. The Old Believers had become a diverse and loosely cohesive religious group that consisted of an increasing number of smaller branches and factions (soglasiia/tolki), who could not reach agreement on core theological issues [Zenkovsky 2009, Melnikov 1999, Staroobriadchstvo 1996]. Thus, it is necessary to take into account the distinctions of each particular soglasie and tolk when discussing Old Believer history, teachings, writings, beliefs and folklore. The study of the development of some genres of their folklore, in particular, religious songs (dukhovnye stikhi) presents two additional challenges. Firstly, a large body of religious songs became an inseparable part of the Old Believer written tradition; they were recorded and copied into Old Believer manuscript books. At the same time, religious songs were routinely performed on different ritual occasions or for entertainment. Often the oral and written repertoires of religious songs do not fully coincide [Filosofova 2010: 14-34; Nikitina 1989: 149-161; Nikitina 1993]. Therefore the study of regional repertoires of religious songs and poetry in a particular manuscript or oral tradition has proved to be the best approach to examine the large and diverse body of religious folk songs [Buchilina 1999; Malushev 1960; Nikitina 1982: 91-126]. Secondly, the development of the body of religious songs and poetry in the manuscript tradition is quite distinctive. Once a folk text (in our case, a religious song) was included in a manuscript book, it was copied, edited and circulated in the same way as any other literary text intended for reading.

The abovementioned issues have been central to the research presented here. This article aims to give an account of the body of eschatological folk songs and poetry known in the manuscript tradition of Russian Old Believers of the bespopovtsy pomorskogo soglasisia (the priestless faction that originated in the Northern regions of Russia) who have been living in the Eastern

FOLKLORICA 2013, Vol. XVII 
district of Latvia (the Latgale) since the end of the $17^{\text {th }}$ century. Over the years this 350-year old community, along with the Old Believers of Riga (Grebenshchikov parish), became a cultural, religious and educational centre for the Old Believer "bespopovtsy" branch in Europe, outside of Russia.

Material Used for this Research

This article is based on a catalogue that I compiled [Filosofova 2010: 227-307], while studying manuscript collections from the former Soviet Baltic republics held in the Drevlekhranilishche IRLI (St Petersburg, Russia). The complete Baltic Collection of Drevlekhranilishche was created as a result of nearly fifty years of annual expeditions carried out by specialists at Pushkin House to the Old Believer regions of Latvia and Estonia [Malyshev 1978; Markelov 1989: 410-438]. This is the largest and most complete manuscript collection of the bespopvts-pomortsy of the Baltic States. In particular, the manuscript tradition and written repertoire of the Latgalian Old Believers is represented in two collections:

- A private collection of 354 manuscript books and hectographs gathered by a prominent and well respected Old Believer scholar, I. N. Zavoloko (1897-1984) who used his knowledge and expertise of Old Believer history and culture (indicated by Zav. below).

- The Latgalian collection of 462 manuscripts and hectographs based on result of field work in Eastern Latvia (indicated by Lat. below).

It is worth noting that religious folk songs and poetry form approximately $15 \%$ of the whole written repertoire of Latgalian and Zavloko collections and are mainly recorded in manuscripts dating from the middle of the nineteenth century and 1930s. The compiled catalogue contains more than a thousand religious folk songs and poems and religious poetry composed both by known and anonymous writers. It would be safe to conclude that the material available for our use represents the comprehensive overview of the development of the repertoire of religious folk songs and poetry in the manuscript tradition of the Latgalian Old

FOLKLORICA 2013, Vol. XVII 
Believers in a period spanning the second half of the nineteenth century and the first quarter of the last century.

Local men of letters included religious folk songs and poems either in special anthologies (stikhovniki) or as a part of collections of legends, apocrypha and didactical texts compiled from various quotations. Up until today, the Old Believers of the Latgale managed to preserve and develop their ancient singing tradition using the medieval Russian neumatic notation (kriuki/soli). The majority of stikhovniki in the Latgalian collections texts are accompanied by neumatic notation that indirectly attests to a solid knowledge and use of such notation in local communities in the last two centuries. The Latgalian manuscript tradition has another distinctive feature - the circulation of books produced by hectographs, (2) which include anthologies of religious songs and poems. It is worth noting that such basic copying equipment as the hectograph produces 100 copies at a time. Therefore, any text included in books made by hectographs was likely well known and widely circulated in the local tradition. Many eschatological songs and poetry were included in hectographic Stikhovniki and that fact, undoubtedly, helped to ensure their popularity among local communities.

The Body of the Eschatological Folk Songs and Poetry of the Manuscript Tradition of the Old Believers of the Latgale

Before we examine the particularities of eschatological folk songs and poetry in the manuscript tradition of the Latgale Old Believers, it will be necessary to establish what eschatological songs and poems were known to local communities. As was mentioned earlier, eschatological beliefs and teachings form the core of the Russian Old Believer theological doctrine. Therefore, not unexpectedly, folk songs and poetry about sin, punishment, death, the end of the world, the realm of the Antichrist and the Second Coming, became the largest and most representative type of oral literature known to the Old Believers, as it reflected the eschatological essence of their religious teaching. The repertoire of the Latgalian Old Believer communities is no exception. The large

FOLKLORICA 2013, Vol. XVII 
and diverse group of eschatological songs and poetry includes songs and poems borrowed from mainstream religious folklore and texts produced by the Old Believers themselves. The body of the eschatological songs and poems circulated in Latgalian manuscripts can be divided into five thematic subgroups:

1. Global eschatology: songs and poems about the end of the world, the Last Judgement and God's punishment that aim to horrify the sinners.

2. Global eschatology: songs and poems that provide a quite detailed and personified image of the Antichrist.

3. Global eschatology: satirical poetry that mocks the vices and sins of contemporary society.

4. Personal eschatology: songs and poems about death that are commonly called in manuscripts "poems on the separation of the soul from the body".

5. Personal eschatology: penitential songs that focus on personal remorse and catharsis.

The following table provides some selected examples of the most popular texts that represent all five groups:

Global eschatology:

\begin{tabular}{|l|l|}
\hline Themes & Examples \\
\hline $\begin{array}{l}\text { Songs/poems } \\
\text { dealing with }\end{array}$ & "You, man, climbing the Mount of Sinai..." \\
issues of the & "Vzyde ty, cheloveche, na Sionskuiu goru..."); \\
end of the & "Our Lord is coming at midnight, the Groom is \\
world, the & $\begin{array}{l}\text { coming in full glory ..." ("Gospod' griadet v } \\
\text { polunoshchi, zhenikh idet so slavoiu..."); "When } \\
\text { Second } \\
\text { Couring } \\
\text { their sins..." ("Egda pridet Gospod" suditi komu } \\
\text { zhso po grekham vozdati..."); "When the } \\
\text { Judgement Day is coming ..."("Egda pridet } \\
\text { Strashnii Sud..."); "The current years are moving } \\
\text { fast, the end is near..."("Idut leta sego sveta, } \\
\text { priblizhaetsia konets..."); "God has punished us } \\
\text { for our sins by sending misfortune upon our }\end{array}$ \\
\hline
\end{tabular}

FOLKLORICA 2013, Vol. XVII 


\begin{tabular}{|c|c|}
\hline & $\begin{array}{l}\text { land..."("Po grekhom nashim, na nashu stranu } \\
\text { popustil Gospod' takovu bedu..."); "The Lord } \\
\text { descends in the year of the eight thousand..." } \\
\text { ("Pridet Gospod'v os'moi tychiache..."); "The } \\
\text { prophecy by the prophet Isaiah has already come } \\
\text { through..." } \\
\text { ("Uzhe prorochestvo sovershilos" proroka } \\
\text { Isai..."). }\end{array}$ \\
\hline $\begin{array}{l}\text { Songs/poems } \\
\text { defying the } \\
\text { Antichrist }\end{array}$ & $\begin{array}{l}\text { The poem about the Antichrist "What is happening } \\
\text { today..." (Stikh ob Antikhriste "Chto na nyneshnee } \\
\text { vremia..."); "The last days have come" ("Uzhe } \\
\text { ostanoshnoe veki ..."); "When the world ends ..." } \\
\text { ("Egda pridet konchina sego sveta..."); "The evil } \\
\text { Antichrist was born..." ("Narodila zloi } \\
\text { Antikhrist..."). }\end{array}$ \\
\hline $\begin{array}{l}\text { Satirical } \\
\text { poems }\end{array}$ & $\begin{array}{l}\text { The poem about tea "What can tea tell us..." ("O } \\
\text { chem govorit chai..."); "The Story about Sins and } \\
\text { Vices of Our Time. Popular Satire" ("O } \\
\text { slabostiakh i nevozderzhaniiakh v poslednie } \\
\text { vremena. Narodnaia satira"); "The Story Told by } \\
\text { the Fool Kirillushka" ("Rasskaz muzhichka- } \\
\text { durochka Kirillushki") and } 7 \text { versions of "The } \\
\text { Newspaper from Hell" ("Gazeta iz ada"). }\end{array}$ \\
\hline
\end{tabular}

Personal eschatology: (3)

\begin{tabular}{l|l|}
\hline $\begin{array}{l}\text { Poems } \\
\text { about death } \\
\text { (on "the }\end{array}$ & $\begin{array}{l}\text { "A man lives on earth as if he is the grass that } \\
\text { grows..." ("Chelovek zhivet na Zemle, kak trava } \\
\text { rastet..."); "Our Lady, please accept your humble } \\
\text { of the soul } \\
\text { from the } \\
\text { body") }\end{array}$ \\
$\begin{array}{l}\text { Bogrvants prayers..." ("Chudnaia Tsaritsa, } \\
\text { "Men, be terrified by those who are above you..." }\end{array}$ \\
$\begin{array}{l}\text { ("Cheloveche, boisia, kto nad toboiu..."); "O, } \\
\text { doves, white doves..." ("Uzh vy golubi, uzh } \\
\text { belye..."); "Death scares a sinner..." ("Strashnaia } \\
\text { est; smert; greshniku..."); "Death pulls out a soul } \\
\text { from a body..." ("Smert; bo dushu iz tela..."); "The }\end{array}$
\end{tabular}

FOLKLORICA 2013, Vol. XVII 


\begin{tabular}{|l|l|}
\hline & $\begin{array}{l}\text { white day is coming to its end..." ( "Beloi den' } \\
\text { korotaetsa..."). }\end{array}$ \\
\hline $\begin{array}{l}\text { Penitential } \\
\text { songs }\end{array}$ & $\begin{array}{l}\text { "Why don't you cry, you who broke God's } \\
\text { law..."("Chto mne ne plachet, prestupivshego } \\
\text { zapoved' vysh vyshniago..."); "What have I done, } \\
\text { what will happen with me..." ("Uvy mne, chto budu } \\
\text { I sodeiu..."); "If only you knew, my soul, the } \\
\text { vanity of this world ..." ("Ashche by vedala dusha, } \\
\text { suety mira sego..."); "A sinner has died..." ("Kako } \\
\text { padokh okaiannyi..."); "Our life is not for ever, the } \\
\text { glory of this world is vanity..." ("Zhitie vremennoe, } \\
\text { slava suetnaia..."). }\end{array}$ \\
\hline
\end{tabular}

"Living in the realm of the Antichrist": Interpretation of the Eschatological Teachings in the Folk Songs and Poetry

The Old Believer eschatological folk songs and poetry shares topics, images, colorful vocabulary, metaphors and religious symbolism of the Russian mainstream eschatological oral literature (this observation is relevant to the Old Believer eschatological oral literature as a whole and especially to that of the bespopovtsy branch). Both eschatological oral literatures, mainstream and the Old Believers', are largely based on the Apocalypse of John and other works by early Christian theologians [Sakharov 1879; Izbrannye tvoreniia 1998] and contain an instructive message for their audience. They remind listeners/readers about the transitory nature of human life and the inevitability of death and depict threatening pictures of the punishments that await all sinners in the afterlife. The eschatological songs and poetry depict the sufferings of mankind at the time of the Second Coming and describe awful natural world disasters such as great storms, floods, earthquakes and gigantic fires on a legendary scale that will occur when the world comes to an end. Many Old Believer eschatological poems contain the following horrifying scenes of "the fallen world":

FOLKLORICA 2013, Vol. XVII 
- A river of fire will sweep all living things from the earth.

- Earthquakes will split the earth in two.

- Mountains will collapse.

- Huge winds will sweep the earth destroying all in their path.

- A gigantic cloud will cover the earth.

- Our world will sink hopelessly in to great misery and darkness.

- All living things will be shaking from an unimaginable horror and suffering, etc.

For example: (4)

Загорится матушка сыра Mother earth will catch fire:

земля:

Со восхода загорится до The fire will spread from East to West,

запада,

С полуден загорится да It will burn from midday to midnight.

доночи.

И выгорят горы с

раздольями,

И выгорят лесы темные.

И сошлет Господи потопие

All the mountains and valleys will

burn,

All the forests will burn.

Our Lord will punish us with a great

flood,

И на три дни, на три месяцы. Which will last for three months and three days.

(Lat. 204)

И течет по земле речка

огненна,

Пламя пышет из реки до

земли.

The river of fire flows over the earth,

A flame from the river burns the earth.

(Zav. 38)

Тогда земля потрясется, In these times an earthquake will

occur,

Камение все распадется,

Церковная завеса

разрушится ....

All stones will fall,

The foundation of the Church will collapse.

(Lat. 261)

However, the bespopvtsy Old Believer branch, in particular, is especially persistent in conveying one central idea, namely that

FOLKLORICA 2013, Vol. XVII 
the Antichrist has already descended to earth and the world has fallen into his hands. This issue lies at the heart of bespopvtsy teachings and, as a result, a sense of urgency is reflected in all their literary work and eschatological folk songs and poetry. Therefore, their folk tradition has a distinctive flavor when compared to mainstream Russian religious oral literature. The artistic (i.e., literary) time of the Old Believer eschatological poetry coincides with the present (perezhivaemoe vremia). Therefore, whenever a poem is read, the audience feels that it is living in the dire realm of the Antichrist. In the eschatological poems, two literary devices are employed to describe the present as the "end of days". First, past perfective verbal forms dominate. The use of the perfective verbs is a grammatical indication of the concept that actions that have occurred in the past have reached their logical end in the present.

For example: (4)

Пришли времена лютые, Пришли годы тяжкие:

Не стало веры истинныя, Не стало стены каменныя, Не стало столпов крепких,

Погибла вера христианска Не могу быть без рыданья. Страх Антихристов мир устрашил, Милость с лестию в мир пометал.
Brutal times have come, Harsh years have arrived: There is no true faith, There is no stone wall, There are no strong foundations,

The Christian faith has perished. I cannot stop sobbing. The fear of the Antichrist has terrified our world; the Antichrist has mixed good with evil.

(Zav.2)

Secondly, the constant refrain of epithets referring to the "end times" throughout this eschatological poetry conveys the urgency of situation. In Old Believers' poems, the present is described as poslednie veki ("final centuries"), ostanoshnye vremena ("the remaining times"), poslednie vremena ("the end times"), posledniia konchina ("the final end"). For example:

FOLKLORICA 2013, Vol. XVII 
Уже останошные времена,

Уже последняя кончина,

Народился злой антихрист,

Злой антихрист - дух нечистый ....

Последние ноньче веки, Что в растлении живут молодые человеки ...
The last days have come, Everything has reached its end.

The evil Antichrist has been born,

The evil Antichrist - the diabolical force.

(Lat. 48)

Now is the end time, Because young people are living in debauchery.

(Zav.42)

However, some poems (for example, "The poem about the Antichrist") point out the time that we all should expect to be our last days by a precise figure os'maia tysiacha ("the eighth millennium"). It is likely that the folk tradition borrowed this carefully circulated "date" of the fall of the world from two very popular readings among the Old Believers - Kirillova kniga (The Book of Kirill) [1644] and Kniga o vere (The Book about the Faith) [1648]. These books were the last books to be published in Moscow before the Church reform and were highly respected by the Old Believers. They interpreted many of the issues discussed in both volumes as firm evidence that the Old Believers were correct in their teachings, including the fact that the end of our days would be 8 thousand years from the creation of the world, which apparently coincided with the seventeenth century CE.

The Figure of the Antichrist

As a result of the belief that the end of days had already arrived, the Old Believers of the "bespopvtsy" branch were obsessed with the idea of the reign of the Antichrist, who plays a central role in the songs [Belousov 1979:3-12; Belousov 1980]. Their eschatological folk poetry provides a vivid and horrifying portrait of this figure. In some poems, the Antichrist is depicted as a soulless demonic force who aims to destroy Holy Russia and all

FOLKLORICA 2013, Vol. XVII 
living beings. Even all saints, the protectors of mankind, are powerless against this force.

Сошлет Господь пророчество, Илью пророка и Онофрия И сойдет на землю бездушный бог, Бездушный бог Антихристос: Он поколет святое пророчество.

От той-то от святой крови

Загорится матушка сыра-земля.
Our Lord will send his prophets, The prophets Elias and Onofrey And the heartless god, the heartless god Antichrist will descend to the earth:

He will destroy these holy prophets.

And from the holy blood of these saints

The mother earth will catch fire.

(Zav 38)

The most common epithets describing the Antichrist describe his frightening appearance and destructive nature. The eschatological poems portray him as "the ten-horned beast" (desiati-rozhnyi zver'), "the seven-headed monster" (sedmiglavyi zmii), "the damned monster" (zmii, sobaka) etc:

Уже Антихрист народился,

Змий собака воцарился ...

Погибла вера християнская .... .....

Десяти-рожный зверь сия погубил,

Седмиглавый змий тако учини ...
The Antichrist has already been born, The damned monster has established his realm The Christian faith has perished.

The ten-horned beast has destroyed this, The seven-headed monster has as well.

(Lat.271)

The folk poetry explains that the Antichrist brought to this world a great number of temptations, and he attempts to catch as many people as he can in his "invisible net." His invisible net is a metaphorical representation of the Antichrist's attack on humanity:

FOLKLORICA 2013, Vol. XVII 
Народился злой антихрист, The evil Antichrist has been born,

Злой антихрист - дух нечистый. The evil Antichrist the spirit of darkness.

Он рассеял свою прелесть

По всей матери вселенной.

Разметал он свои сети

По всему своему царству.

Он и станеи всех прельщать,

В свои сети уловлять.

He spreads his temptations

Across the whole of mother earth.

He has spread his nets

Throughout his kingdom

He has started to seduce us all,

In order to catch us in his nets.

(Zav.10)

Many poems concerned with the figure of the Antichrist provide an instructive message that the Antichrist's realm and the horror of our last days is a well-deserved punishment from God for the awful sins of humanity. The unforgiveable sin, as was understood by the Old Believers, was, of course, Nikon's Church reform and the loss of the true Orthodox faith that inevitably led the world to the fall, as we see in this song:

$\begin{array}{ll}\text { Церкви Божия истребишася, } & \begin{array}{l}\text { God's churches have been } \\ \text { destroyed, }\end{array} \\ \text { Тайнодестия вси лишишася, } & \text { We have lost all our sacraments. } \\ \text { Но и пастыри попленилися, } & \begin{array}{l}\text { Our priests have been imprisoned } \\ \text { Жалом диявола умертвилися ... }\end{array} \\ \begin{array}{l}\text { And murdered by the devil's } \\ \text { stings. }\end{array}\end{array}$

(Zav.10)

Analysis of the many complex theological matters of the Old Believer doctrine forms a separate scholarly subject and is beyond of the scope of this article. However, even a brief examination of the Old Believer eschatological poetry concerning the end of the world and the realm of the Antichrist allow us to make two observations that are essential for the current discussion. First, the Old Believer folk tradition fits the general pattern of mainstream religious folklore by being highly selective in its objects for interpretation. Popular imagination chooses only those basic ideas that can be easily explained and understood by a general audience. The prominent Russian scholar F. I . Buslaev considered

FOLKLORICA 2013, Vol. XVII 
mainstream religious poetry to be "a bridge" between Christian and folk cultures [Buslaev 1990:295]. I suggest that the Old Believer eschatological poetry served a similar function in their culture and became "a bridge" between the Old Believer theological teachings and the popular imagination of those that followed these teachings. For example, the firm belief that Nikon's Church reform was the reason for the fall of the last stronghold of Christianity into the hands of the Antichrist became the core of their ideology. It was broadly accepted by all followers of "the old piety" and transferred to the folk poetry as shown in the examples above. Secondly, the eschatological folk poetry of the Old Believers has another distinctive feature. However terrifying the content of poems about the end of the world and the Antichrist is, none of the poems refer to the absolute demise of mankind. This indirectly gives the audience hope of finding ways to salvation. These aspects are also seen in another group of Old Believer poems: satirical folk poetry.

Satirical Poetry by the Russian Old Believers: The Evil and Tempting World

According to Old Believer teachings, historical time stopped for Orthodox Christianity when Nikon's Church reforms were fully and finally implemented and a border was drawn between "the saviors of the old piety" and the rest of the world, which had turned from the light of the true faith to the darkness of Hell. The Old Believer communities became the last stronghold of religious piety in what they saw as this hostile, evil world full of temptation. However, in their writings and folklore, Old Believers were keen to expand their knowledge of this outside and "evil" world to protect themselves from its temptations. Therefore, their fundamental mission was to preserve their way of life, including everyday customs, ideology, church services and books, from the rest of the world. They set, in the figurative sense, a spiritual border (ograda), between themselves and the world ruled by the Antichrist. For example, in the Old Believer eschatological folk poetry, the most common epithet used to describe the world, is

FOLKLORICA 2013, Vol. XVII 
"evil and full of temptations" (zloi $i$ prelestnyi). Since the world "had fallen", Old Believers resisted every new aspect of everyday life. As time passed, with the world still under the rule of the Antichrist, any new temptations from the outside world were considered to be the "intrigues of the Devil" (kozni Satany). New food and drinks (such as tea and potatoes), new customs (smoking tobacco, shaving beards), new ways of conducting church services, the latest fashions and later, even new technologies (computers, the Internet) were condemned and mocked in their literary and folk traditions. In particular, they employed satire, irony and mockery to show their disgust and loathing for the outside world. They established a distinctive form of religious satirical folk poetry rooted in the genre of Russian satirical novels, which reached the peak of their popularity during the seventeenth and eighteenth centuries [Adrianova-Peterts 1977: 110-115]. This genre served the task of debasing, through mockery, the customs and occurrences in the "evil side" of society. These songs are based on the medieval principle of the carnival and the concept of the otherworld [Likhachev 1984: 16]. The Old Believers gave new life to satirical folk poetry, producing funny, sharp-witted texts with colloquial language and memorable images and metaphors. The body of the Old Believer satirical folk poems is very large and covers almost every aspect of our sinful everyday existence in the "evil world" that, in the Old Believer interpretation, deserves mockery and loathing. The Latgalian manuscript collections feature four satirical folk poems which are good examples of this type of genre in Old Believer tradition. They include: Reader, take note of what tea tells us..."( "O chem govorit chai, a ty, chitatel" zamechai...") , "The Story of Our Time"("Istoriia nyneshnego veka"), "The Story Told by the Fool Kirillushka" ("Rasskaz muzhichka-durochka Kirillushki") and "The Newspaper from Hell"("Gazeta iz ada").

"The Newspaper from Hell" is one of the most popular satirical texts among Old Believers of different branches [Budaragin 1995; Rozhdestvensky 1910 (1900)]. The poem was well known to Latgalian Old Believers and can be found in their manuscripts in seven original variations in six copies dated

FOLKLORICA 2013, Vol. XVII 
between the end of the nineteenth and beginning of the twentieth centuries. A detailed examination of Latgalian versions of this poem can improve our understanding of how a literate Old Believer edited and modified popular texts. As expected the Old Believer men of letters followed a well-established method of editing and modifying a written text as had been done for centuries in mainstream medieval Russian Orthodox manuscript tradition. Among the most common methods of modifying a text are the creation of a short and a full edition of the text with flexible content and using a certain traditional format ('template') for creating the compiled versions of various texts. For instance, a Latgalian variation of the "Newspaper from Hell" from a manuscript dated to the beginning of the last century (Lat. 358) provides us with a fine example of the use of a list of sins and sinners as a traditional 'template' for this popular poem. However, a local man of letters made his contribution to the development of the text by giving to each sin and sinner a subtitle and a number:

1 О грешниках

2 О пьяницах

3 О блудниках

4 О господах

5 О чернецах

6 О окупщиках и т. д.

\author{
1 About sinners \\ 2 About drunks \\ 3 About fornicators \\ 4 About the privileged man \\ 5 About monks \\ 6 About pawnbrokers, etc. \\ (Lat.358)
}

The order of the sins and sinners in this list deserves special attention and provides us with an insight to how the folk imagination interpreted the degree of each sin and the punishment that each sin deserves. I suggest that the order of these sins is from the lesser sin to the deadliest one. According to the description, the drunks who were placed in the beginning of the list would be told off and kicked by Satan:

Сатана дал тычек ему (пьянице $T \Phi)$ и приказал внуку, чтоб его испросил,
Satan kicked him (a drunk - TF) and ordered his grandson to interrogate the drunk to find out

FOLKLORICA 2013, Vol. XVII 
Кто его ис пиянства так

who tempted him with drink...

искусил...

(Lat. 358)

It is commonly known that smoking and sniffing tobacco were considered to be mortal sins by Old Believers. The local version of the "Newsletter from Hell" confirms this contention. The smokers are placed at the end of the list and can expect severe physical punishment, such as the pulling out of his nostrils with sharp hooks and bathing in boiling pitch:

(Сатана) приказал принести отстрые крючки, прочистя носы табачны.

Приказал со смолой месить квашни.
(Satan) gave the order to bring sharp hooks

To clean the noses of the tobacco users.

He also gave the order to prepare hot pitch.

(Lat.358)

Some of the satirical poems produced by the Old Believers were inspired by the list of rules regulating everyday life and customs of good Christians (zapretitel'nye ustavy). For example, in the poem about tea "Reader, take know of what tea tells us..." ("O chem govorit chai, a ty, chitatel' zamechai...") serves as one example of such a text included in Latgalian manuscript books (Begunov 1972: 244-248).

Finally, Latgalian collections include a single copy of a rare satirical text - "The Story Told by the Fool Kirillushka" ("Rasskaz muzhichka-durochka Kirillushki"). The poem was not circulated elsewhere and was likely composed by an anonymous local. In this text the narrator, who calls himself Kirillushka the fool, describes how he visited the Pope, who drowned in his horrible sins of sodomy and blasphemy:

В самом Риме я был, С папой вместе гостил.

Имя Папе Макар, Он не так еще стар.

Ну уж лет ща полста,
I have been in Rome

I stayed at the Pope's

His name is Makar,

He is not that old, In his fifties perhaps.

FOLKLORICA 2013, Vol. XVII 
А все хулит Христа.

Ненавидит креста

И не имеет поста.

И живет с Папой втай

Казачок Оплетай.

\author{
And he still scolds Christ \\ He hates the cross, \\ He does not observe Lent. \\ He took his serving man called \\ Opletay as his lover. \\ (Zav.66)
}

The poem also provides us with deep insight into the popular interpretation of wealth as it might have been understood in a rural farming community:

Папа очень богат, Он и землю купил и дом новый срубил. Для быков и коров Он настроил дворов, Жеребцов и кобыл Табуны наплодил.
The pope is very wealthy He bought some land and built a new wooden house. He also built many cattle-sheds For his bulls and cows, He multiplied The herds of horses.

(Zav.66)

It is evident from the above example that the world view reflected in Old Believer satirical poetry has two layers: the down-to-earth peasant concept of well-being and a firm Christian belief in Old Believer interpretation thereof. This particular poem distinguishes itself from the majority of poetry of a satirical nature by focusing on the close examination of a corrupt world ruled by diabolic force.

\section{Personal Eschatology and Penitential Songs}

Folk songs and poetry concerning death, afterlife and the inevitable punishment of all sinners is considered to be "personal eschatology" [Fedotov 1991 (1935):105] as opposed to global eschatology dealing with the Apocalypse. Songs and poems concerning various aspects of personal eschatology contain instructive messages. They remind the audience about the transitory nature of our lives and the inevitability of death and draw horrific pictures of the punishments that await all sinners in

FOLKLORICA 2013, Vol. XVII 
Hell. The topics of personal eschatology were held dear by Old Believer communities, and the Latgalian tradition is no exception in this regard. Local men of letters borrowed a large number of poems about death and the afterlife from mainstream Russian religious folk songs and poetry. In some Old Believer communities these songs were sung as a part of the traditional funeral rites and at besedy (parties for women who gathered to knit and sew) during Lent. (4) Extracts from mainstream folk poems concerning the punishment of sinners after their death appeared in the lubki, popular books including cheap art reproductions in the eighteenth and nineteenth centuries aimed at reaching a wide audience. Naïve folk images in the lubok style were much beloved in Old Believer communities and were used to decorate houses. (5)

Penitential songs and poems on "the separation of the soul from the body" were especially popular in the Latgale. Like the songs related to personal escatology, songs and poems of this type were borrowed from mainstream Russian religious folklore. However, in Latgale songs and poems about sin, death and afterlife, as well as the satirical poetry, became an area of creativity. Latgalian collections include a few poems by local writers that deal with personal eschatology. Many authors followed a method of compiling or editing quotations from various well known texts to produce their own verses. This method was very common in Old Believer writings as a whole and especially for religious songs and poems. Each text produced by this method of compilation merits individual examination and can provide us with interesting and unpredictable results. I will give only one example, the very popular religious song "Wonderous Empress, Mother of God, please accept your humble servant's prayers..." ("Chudnaia Tsaritsa, Bogoroditsa, uslysh' molitvu rabov tvoikh...") was borrowed by the Old Believers of Latgale from the mainstream folk repertoire and has been used as core material, along with some other texts, to produce several independent texts, including "The white day is coming to its end, beautiful sun is going down..." ("Beloi den' korotaetsia, krasno solntse zakataetsia...") and "The evening is approaching..." ("Den' idet ko vecheru...").

FOLKLORICA 2013, Vol. XVII 
Synthetic Nature of the Oral Literature of the Old Believers

Old Believer ideology, culture, literary traditions and folklore have a peculiarly syntactical nature that resulted from practical necessity and the desire of this particular religious dissident movement to recreate an old medieval Orthodox cultural model applicable to a new, ever-changing historical, political and social environment. In particular, in developing their own writings and oral literature, the Old Believers employed borrowing, compilation of, and quotations from texts and ideas, mainly from the work of early Christian theologians, apocrypha and mainstream Russian religious folklore they deemed suitable. Over time, literate Old Believers relied on the wealth of these borrowed materials as the main sources for their own didactical, polemical and literary works covering a broad range of theological, philosophical and moral issues. Old Believer oral literature has thus developed along similar principles as the literary tradition. It offers a unique blend of religious folk songs, poetry and narratives, borrowed from mainstream religious folklore, Old Believer oral literature, early Christian penitential songs and works by anonymous and well-known Russian authors.

Christian folk poems from the mainstream Russian religious folk repertoire and old penitential poems by Orthodox monks were particularly cherished and enjoyed great popularity in Old Believer circles. They were acknowledged by writers as meeting the norms of religious devotion and they became an important element in the creation of a cultural base on which Old Believer Christian literature was built. In simple and accessible language, these texts spoke of basic Christian doctrine and instructed in the faith and related, in didactic fashion, the main events of Christian history. The devout were expected, in their spare time, to create models of these texts in order to promote a pastime, which was, in the words of the Old Believers "dignified with piety" (blagochestivoe vremiapreprovozhdenie). The religious poetry and songs, both folk and literary, became an area of creative work in the Old Believer communities and continues to develop as a living tradition even today.

FOLKLORICA 2013, Vol. XVII 
As mentioned above, the Old Believer folk tradition is largely based on mainstream Russian religious songs and narratives. However, it has some very distinctive features. First of all, oral literature became an inseparable part of the Old Believer written manuscript tradition, a result of their interpretation of learning and reading from medieval Russia. Books, both printed and manuscripts, have always held unquestioned authority among "the saviors of old piety" (khraniteli drevliago blagochestiia). In the words of the Old Believers, reading an appropriate book was considered to be a process to rediscover "God's true knowledge," essential for the "formation of the soul," rather than the for the process of learning new things, and provoking questions and thought [Bubnov 1998:51, Pozdeeva 1998:15]. The importance of keeping and preserving the past as a model to be copied and repeated again and again was understood as a basis of education. Therefore, all oral literature considered appropriate for "the saviors of old piety" was recorded and circulated within the communities as manuscripts and, later, in printed volumes as well. To be included in a book, a text had to correspond to one universal criterion set for all written work within Old Believer communities: it must educate a Christian soul according to the Old Believer teachings ("to be good for the soul"). The subtitle dushepolezny ("good for the soul") appears to be the most common one in the Old Believer collections of religious folk songs and poetry. In the Old Believer communities, the mainstream dukhovnyi stikhi were sung, preferably from a book. (5) However, most of the religious poetry produced by the Old Believers themselves was intended for reading rather than singing. They were composed using a complex syntax, a dominance of Church Slavonic vocabulary and often lack rhythm.

Four important conclusions about the intersection of the folk and manuscript traditions may be drawn from this analysis of the eschatological songs and poetry in the manuscript tradition of the Latgale Old Believers. Religious folk songs and poetry have been considered to be "a bridge" between formal theological teachings and popular imagination. They served to translate the core aspects of teachings to a general audience and made them

FOLKLORICA 2013, Vol. XVII 
appealing to everyone. Eschatological folk songs and poems focused, in particular, on the most important doctrinal matters. For example, the timing of the end of the world was firmly linked to the Church reform of 1653-1666 in both formal Old Believer doctrine and popular interpretation of the event. The figure of the Antichrist also drew much attention in folk and authored poetry by the Old Believers. His personality and signs of his realm on Earth were vigorously investigated in the popular songs. In addition, the Old Believers developed satirical poetry, an original means to protect "the truth faith" by mocking the outside world for all its faults and temptations and by exposing human vice and sins. Of particular note is the fact that personal eschatology, especially penitential songs, is well represented in Latgalian manuscripts due to the successful preservation of the singing tradition, using neumatic notation, which has enabled the development of hymnography in the local musical manuscript tradition up to the present day. Finally, compilation of several texts and/or authored variations built on a fragment, theme or line of a popular folk text proved to be the most common method implemented in the manuscript tradition. It would be fair to say that the Old Believers inherited this method from the medieval written tradition and used it as a core method to develop their own writings and compilation of manuscript books. Eschatological songs and poetry from the Latgale are particularly good illustrations of this compilation method.

As mentioned above, the Old Believers of the Latgale today are a fully functional community that strives to pass on their wellpreserved cultural heritage and traditional values to the next generation. As an important figure of that community, Father Alexii Zhilko, Chairman of the Central Council Pomeranian Ancient Orthodox Church, stated to me in an interview, "to be a Russia Old Believer today means to have the Old Believer mentality". I would suggest that the very rich and diverse body of eschatological songs and poetry that has been preserved and developed in living Latgalian tradition equip us with an essential tool required for a better understanding the mentality and culture of this group.

FOLKLORICA 2013, Vol. XVII 


\section{NOTES}

1 Patriarch Nikon (1605-1681) initiated and led the Russian Orthodox Church reform. The reform, to unify Church services and edit translated Holy books, was carried out between 1653 and 1677 and became a prolonged, difficult process and proved to be controversial. The comprehensive review of the Old Believer movement can be found in [Zenkovsky: 2009, Melnikov 1999]. A very detailed review of works by theologians that influenced ideology, literature and folklore of the Old Believers and mainstream Russian religious folklore can be found in [Sakharov 1879, Belousov 1979: 3-12, Belousov 1980, Gur'ianova 1996, Zenkovsky 2009].

2 Hectographs are a basic copying device.

3 The majority of songs of this group were borrowed from mainstream religious folklore.

4 In the original, all verbs are given in italics and are used in the past perfect form. However when translated in English, the verbal forms do not always coincide, e.g., to be.

5 This observation is based on my fieldwork among the Russian Old Believers in Dugavpils in 2007-2010.

\section{ARCHIVAL MATERIALS}

All numbers of the manuscripts are provided according to the Catalogue of the Manuscripts of the Drevlekhranilishche im. V. I. Malusheva, IRLI, St Petersburg. Accepted Abbreviations:

Lat. - Latlalian Manuscript Collection

Zav - The Collection of I. N. Zavoloko

\section{BIBLIOGRAPHY}

Adrianova-Peterts, V., 1977. Адрианова-Перетц, В. Русская демократическая сатира [Russian democratic satire]. Москва: Наука.

FOLKLORICA 2013, Vol. XVII 
Belousov, A. F. 1979. Белоусов, А. Ф. “О влиянии старинной письменности на мировоззрение русских старожилов Прибалтики" [An Influence of the Old Written Literature on the World View of the Russian Settlers in the Baltic States] in Учение записки Тартусского государственного университета. Труды по русской и славянской филологии XXXI. Литературоведение. № 491. Тарту: ТГУ.

Belousov, А. F. 1980. Белоусов, А. Ф. Литературное наследие древней Руси в народной словесности русских старожилов Прибалтики. Автореферат диссертации на сооискание ученой степени кандидада филологических наук [Influence of the Old Russian Literature Heritage on the Oral Literature of the Russian Settlers in the Baltic States. Summary of the Dissertation]. Тарту: ТГУ.

Bubnov, Nikolai. 1998. Бубнов, Н. Старообрядческая книга третьей четверти XVII века как историкокультурный феномен [The Old Believer Books of the Third Quarter of the 17th Century as Historical and Cultural Phenomenal]. Ленинград: Наука.

Buchilina, Е. А. 1999. Бучилина, Е. А. Духовные стихи. Канты. Сбоник духовных стихов Нижегородской области. [Religious Songs. Chants. Religious Songs from Hizhnegorodsky district]. Москва: Наследие.

Budaragin, V. Р. 1995. Бударагин, С. П. "Газета из ада (по материалам Дрелехранилища Пушкинского Дома)" [The Newspaper from Hell (based on the manuscript collections kept in the Drevlekhranilishche IRLI)] in Русские утопиии. Канун.Альманах. Вып. II. СПБ: ИРЛИ.

Buslaev, F. I. 1990. Буслаев, Ф. И. Избранное. О литературе. [Selected Publication on Literature]. Москува: Наука.

Burgaft, S. G. and Ushakov I. A. 1996. Бургафт, С. Г., Ушаков, И. А. Старообрядчество: Лица, события, предметы и символь. Oпьт энциклопедического словаря. [The Old

FOLKLORICA 2013, Vol. XVII 
Believers: People, Events, Subject and Symbols. The Encyclopaedic Dictionary]. Москва: Церковь.

Fedotov, G. Р. 1991 (1935). Федотов, Г. П. Стихи духовные (руская народная вера по духовным стихам). [Russian Religious Folk Songs (Russian Popular Beliefs as they appear in Russian Religious Folk Songs]. Москва: Прогресс, Гнозис.

Filosofova, T. V. 2010. Geistliche Lieder der Altglaubigen in Russland. Bohlau Verlag Köln.

Gur'ianova, N. S. 1996. Гурьянова, Н. С. История и человек в сочинениях старообрядиев XVIII века [History and Man in the Literary Works by the Old Believers in the 18th Century]. Новосибирск: Наука. Сибирское отделение.

Izbrannye tvoreniia sviatykh ottsov, 1998. Избранные творения святых отиов [Selected Works by Recognized Orthodox Teachers]. Москва: Церковь.

Kirillova Kniga. 1664. Кириллова книга: Книга июе во святых отиа намего Кирилла, архиепископа Иерусалимского на осмий век [The Book of Kirill by our Archbishop of Jerusalem in the 8th millennium]. Москва: Печатный двор.

Kniga o vere sviatoi, istinnoi i pravoslavnoi $i$ osviashchennoi tserkvi vostochnoi. 1648. Книга о вере святой, истинной и православной и освященной церкви восточной (издана тщанием о. Ст. Вонифатьева) [The Book about the Faith]. Москва: Печатный двор.

Krotov, Y., Кротов, Я. "Русская Православная церковь" [Russian Orthodox Church in Soviet Times], http://krotov.info/acts/20/1970/shtric_15.htm (Consulted 1, February, 2013).

Kuraev, Andrei, Кураев, Андрей “Доклад Митрополита Ленинградского и Новгородского Никодима на Поместном Соборе 31 мая 1971 г." [A Report by the Bishop of Leningrad and Novgorod District at the Church Coucil], http://kuraev.ru/smf/index.php?topic=32865.0

(Consulted 8, March, 2013).

FOLKLORICA 2013, Vol. XVII 
Likhachev, D. S., Panchenko, A. M., Ponyrko N. V. 1984. Лихачев, Д. С., Панченко, А. М., Понырео, Н. В. Смех в Древней Руси [Laughing in Medieval Russia]. Ленинград: Наука.

Malyshev, V. I. 1960. Малышев, В. И. Усть-Цилемские рукописные сборники XVI-XX вв. [Manuscript books from Ust'-Tsilma of the XVI-XX centuries]. Сыткывкар: Коми Изд.

Malyshev, V. I. 1978. Малышев, В. И. Древлехранилище Пушкинского дома. [Drevlekhranilishche IRLI ]. Ленинград: Наука.

Markelov, G. V. 1978. Маркелов, Г. В. “Коллекция рукописей И. Н. Заволоко" [Zavoloko Manuscript Collection], Tpydbl Отдела Древнерусской Литературы. [Works of the Department of Ancient Russian Literature]. T. 34. Ленинград: Наука.

Markelov, G. V. 1989. Маркелов, Г. В. “Латгальская рукописно-книжная традиция" [Zavoloko Manuscript Collection], Трудь Отдела Древнерусской Литературы. [Works of the Department of Ancient Russian Literature]. T. 42. Ленинград: Наука.

Melnikov, F. Е. 1999. Мельников, Ф. Е. Краткая история древлеправославной (старообрядческой) черкви [А Brief History of the Old Believer Church]. Барнаул: Лествица.

Nikitina, S. Е. 1982. Никитина, С. Е. "Устная традиция в народной культуре русского населения Верхокамья" [Oral Tradition of Popular Culture of Russian population of Verkhokamie], Русские письменные и устные традиции и духовная культура. Москва: Наука.

Nikitina 1989. Никитина, С. Е. “О взаимоотношениях устных и письменных форм в народной культуре" [On the Relationship between Oral and Written Forms in Popular Culture], Славянский и балканский фольклор. Москва: Наука.

FOLKLORICA 2013, Vol. XVII 
Nikitina, S. Е. 1993. Никитина, С. Е. Устная народная культура и языковое сознание. [Oral Folk Culture and Linguistic Consciousness]. Москва: Наука.

Pozdeeva, I. V. 1998. Поздеева, И., В. “Комплексные исследования современной традиционной культуры русского старообрядчества. Результаты перспективы” [A Comprehensive Study of the Contemporary Culture of Russian Old Believers], Мир страробрядчества. Живые традищии. Москва: Российская политическая энциклопедия: 12-20.

Pozdeeva, I. V. 1999. Поздеева, И., В. “Личность и община в истории русского старообрядчества" [A Person and a Community in the History of the Russian Old Believers], Мир страробрядчества. История и современность. Москва: Изд-во МГУ: 3-28.

Rozhdenstvensky, T. S. 1910 (1909). Рождественский, Т. С. "Памятники старообрядческой поэзии" [The Poetry of the Old Beivers], Записки Московского Археологического иститута. Т. 6. Москва: Изд-во Сытина.

Sakharov, V. P. 1879. Сахаров, Р. П. Эсхатологические сочинения и сказания в древнерусской письменности и влияние их на народные духовные стихи. [The Old Russian Eschatological Literary Works and Legends and Their Influence on the Religious Folk Songs]. Тула: Типография Н. И. Соколова.

Scheffel, D., 1991. In the Shadow of Antichrist. Broadway Press: Canada.

Subbotin, N. I. 1875-1885. “Субботин Н. И. Материалы для истории раскола за первое время его существования" [Materials Covering the History of the Schism during its first period], V. 5. Москва: Братское слово: 227-228.

The Oxford English Dictionary online: "Eschatology, n.", def. a, Oxford English Dictionary, http://oxforddictionaries.com/ us/definition/american_english/eschatology (consulted 5 July, 2013).

FOLKLORICA 2013, Vol. XVII 
Zenkovsky, S. A. 2009. Зеньковский, С. А. Русское старообрядчестово. В двух томах [The Russian Old Believers. In two Volumes]. Москва: Квадрига. ДИ-ДИК

Zhilko, A., Farther Zhilko, a current Chairman of the Central Council Pomeranian Ancient Orthodox Church of Latvia, DOB 1945, native of Riga, interviewed $01 / 25 / 10$ in Daugavpils.

Zol'nikova, N. D. 1992. Зольникова, Н. Д.““Современный писатель-старообрядец с Енисея” [A Contemporary Old Believer writer from Enisei], Традиционная духовная $и$ материальная культура русских старообрядческих поселений в странах Европь,, Азии и Америки. Сборник научных трудов. Новосибирск: Наука. Сибирское отделение: 283-288.

FOLKLORICA 2013, Vol. XVII 